\title{
Clinical Usefulness of a One-Tube Nested Reverse Transcription Quantitative Polymerase Chain Reaction Assay for Evaluating Human Epidermal Growth Factor Receptor 2 mRNA Overexpression in Formalin-Fixed and Paraffin-Embedded Breast Cancer Tissue Samples
}

\author{
Hye-young Wang ${ }^{a}$ Sungwoo Ahn ${ }^{b}$ Sunyoung Park ${ }^{b}$ Seungll Kim ${ }^{c}$ \\ Hyeyoung Lee ${ }^{b}$ \\ a Optipharm M\&D, Inc., Wonju Eco Environmental Technology Center, and bepartment of Biomedical Laboratory \\ Science, College of Health Sciences, Yonsei University, Wonju, and ' Department of Surgery, College of Medicine, \\ Yonsei University, Seoul, Republic of Korea
}

\begin{abstract}
Key Words
Breast cancer - Immunohistochemistry · Fluorescence in situ hybridization . Human epidermal growth factor receptor 2 overexpression - One-tube nested reverse transcription quantitative polymerase chain reaction . Molecular diagnosis
\end{abstract}

\begin{abstract}
Background: Currently, the two main methods used to analyze human epidermal growth factor receptor 2 (HER2) amplification or overexpression have a limited accuracy and high costs. These limitations can be overcome by the development of complementary quantitative methods. Methods: In this study, we analyzed HER2 mRNA expression in clinical formalin-fixed and paraffin-embedded (FFPE) samples using a onetube nested reverse transcription quantitative polymerase chain reaction (RT-qPCR) assay. We measured expression relative to 3 reference genes and compared the results to those obtained by conventional immunohistochemistry (IHC) and fluorescence in situ hybridization (FISH) assays with $226 \mathrm{FFPE}$
\end{abstract}

breast cancer tissue samples. Results: The one-tube nested RT-qPCR assay proved to be highly sensitive and specific based on comparisons with $\mathrm{IHC}$ ( 96.9 and $97.7 \%$, respectively) and FISH (92.4 and $92.9 \%$, respectively) obtained with the validation set. Comparisons with clinicopathological data revealed significant associations between HER2 overexpression and TNM stage ( $p<0.01)$, histological type $(p<0.01)$, ER status $(p<0.001)$, PR status $(p<0.05)$, HER2 status $(p<0.001)$, and molecular subtypes $(p<0.001)$. Conclusion: Based on these findings, our one-tube nested RT-qPCR assay is a potentially useful and complementary screening tool for the detection of HER2 mRNA overexpression.

(c) 2016 S. Karger AG, Basel

\section{Introduction}

Breast cancer remains the most common malignancy among women and the second most common cause of cancer-related mortality worldwide; the World Health Organization estimates that $25 \%$ of all newly diagnosed

\section{KARGER}

(c) 2016 S. Karger AG, Basel

E-Mail karger@karger.com

www.karger.com/pat
Hyeyoung Lee, $\mathrm{PhD}$

Department of Biomedical Laboratory Science, College of Health Sciences Yonsei University, 1 Yonseidae-gil

Wonju, Gangwon 26493 (Republic of Korea)

E-Mail hyelee@yonsei.ac.kr 
cancer cases are breast cancer and that more than 521,000 women died in 2012 due to breast cancer [1]. In the Republic of Korea, about 16,015 new cases of breast cancer and 2,018 deaths due to breast cancer were estimated for 2012 [2].

Human epidermal growth factor receptor 2 (HER2, also known as ERBB2) is one of the 4 ErbB-like closely related oncogenes. Accurate determination of the levels of HER2 is extremely important for the diagnosis and effective treatment of patients with breast cancer [3]. Approximately $15-20 \%$ of all patients with breast cancer are known to exhibit HER2 overexpression; this overexpression is regarded as a prognostic factor associated with a poor prognosis, early recurrence, and a shorter overall survival time [4]. Patients with a HER2-positive status are eligible for treatment with trastuzumab (Herceptin; Roche, Penzberg, Germany), a humanized monoclonal antibody directed against the extracellular domain of HER2 [5]. Trastuzumab is currently used as the standard first-line treatment for metastatic breast cancer and it is also indicated in adjuvant settings. In neoadjuvant treatment, trastuzumab shows more effective therapeutic activity when combined with other forms of chemotherapy $[6,7]$. Breast cancer therapy is currently selected based on the HER-2 expression level. Thus, reliable detection of the HER2 status is important for selection of the most appropriate therapeutic method for the treatment of breast cancer. It is particularly important to avoid the risk of latent side effects from inappropriate treatment, especially in women who do not exhibit HER2 overexpression [8].

Various methods, including immunohistochemistry (IHC); in situ hybridization; visualization methods such as the use of fluorescence (fluorescence in situ hybridization; FISH), silver probes, and chromogenic probes; polymerase chain reaction (PCR), and reverse transcription PCR [9-11], can be used to determine the HER2 mRNA and protein levels in a given tissue sample. IHC (HercepTest; Dako, Carpinteria, Calif., USA) and FISH assays have been approved for HER2 detection by the US Food and Drug Administration (FDA) and are widely regarded as the gold standards for evaluating HER2 status. These assays determine the HER2 protein expression status according to the percentage of stained tumor cells, with samples scored as $0,1+, 2+$, or $3+$. Patients with an IHC score of $3+$ are classified as HER 2 positive and are eligible for HER2-targeted therapy, whereas patients with scores of 0 or $1+$ are not considered to overexpress HER2 and are therefore unsuitable for HER2 targeted treatment. Patients with a score of $2+$ require confirmation via another method, such as FISH (PathVysion; Abbott Laboratories,
Abbott Park, Ill., USA; INFORM; Ventana Medical Systems, Tucson, Ariz., USA, or and pharmDx; Dako, Glostrup, Denmark). Although multiple aspects of the HER2 IHC assay are subjective, the main source of the subjectivity is the fixation process [11]. FISH can generate quantitative results with better sensitivity and specificity than IHC because it offers standardized cutoff values and a better reproducibility due to the stability of DNA [12]. However, these methods are time consuming and relatively expensive, they require specialized equipment, and they are difficult to standardize across laboratories [13]. Therefore, additional quantitative methods that are complementary to IHC and FISH are needed for the accurate measurement of HER2 expression.

Various molecular techniques based on real-time quantitative reverse transcription PCR (RT-qPCR) are currently being tested as methods for determining the HER2 status. These techniques measure HER2 levels as either gene copy numbers or relative mRNA expression levels. These rapid, simple, and quantitative methods offer an appropriate alternative for the assessment of HER2 gene expression in routine clinical practice [11]. We therefore designed a one-tube nested RT-qPCR assay to evaluate HER 2 overexpression and validated this assay using 226 formalin-fixed paraffin-embedded (FFPE) tissue samples. Finally, we compared the results of our assay with those obtained using IHC and FISH.

\section{Methods}

Clinical Samples

A total of 226 FFPE breast cancer tissue samples were obtained from patients with breast cancer. All patients were treated at the Yonsei University Severance Hospital (Seoul, Republic of Korea) between 2013 and 2014. All subjects provided written informed consent, and the Institutional Ethics Committee of the Yonsei University Severance Hospital approved the study protocol (approval No. 1-2010-0018).

\section{Cell Lines and Cell Culture}

The human breast carcinoma cell lines BT-474 and SK-BR3 (overexpressing HER2) were used as positive controls, while the MCF7 and MDA-MB-231 lines (no HER2 expression) were used as negative controls. BT-474 cells were cultured in RPMI 1640 medium, while all others were cultured in DMEM. Cells were propagated at $37^{\circ} \mathrm{C}$ in a $5 \% \mathrm{CO}_{2}$ atmosphere. All media were supplemented with $10 \%$ fetal bovine serum, $100 \mathrm{U} / \mathrm{ml}$ of penicillin, and $100 \mu \mathrm{g} / \mathrm{ml}$ of streptomycin (Gibco-BRL, Carlsbad, Calif., USA).

\section{Immunohistochemistry}

HER2 status stratification by IHC was performed manually using a Dako HercepTest Kit (Dako, Glostrup, Denmark) according to the manufacturer's instructions. IHC results for the membrane
58

Pathobiology 2017;84:57-70 DOI: $10.1159 / 000447301$
Wang/Ahn/Park/Kim/Lee 
marker HER2 were reported using the Hercepscore scoring scheme, as modified by the American Society of Clinical Oncology/College of American Pathologists (ASCO/CAP) [14], as follows: 0 (negative), $1+$ (incomplete, weak membrane staining in $>10 \%$ of the tumor cells), $2+$ (relatively low overexpression, complete membrane staining in $>10 \%$ of the tumor cells), and $3+$ (strong, uniform complete membrane staining in $>30 \%$ of the tumor cells).

\section{Fluorescence in situ Hybridization}

HER2 IHC 2+ specimens, which have borderline HER2 expression, were subjected to FISH analyses using an HER2 pharmDx FISH Kit (Dako) to confirm the HER2 gene expression level [14]. Amplification status was assessed according to the recommended clinical scoring scheme, which involves counting the HER2 and CEP17 (chromosome 17 centromere; for chromosome 17 enumeration) probe signals in 20 representative tumor nuclei. Then, the HER2/CEP17 ratio is calculated. Briefly, a specimen was considered to have amplified HER2 expression if the ratio was $>2.2$ and the expression was considered nonamplified if the ratio was $<1.8$. If the ratio was within the borderline region of 1.8-2.2, additional tumor cells were counted and the ratio was recalculated. Finally, any ratio $\geq 2.0$ was regarded as amplified.

\section{Deparaffinization of FFPE Tissue and Total RNA Extraction}

Total RNA was extracted from 2 pieces of $10-\mu \mathrm{m}$-thick sections from the paraffin block-embedded FFPE tissue. To remove paraffin from the FFPE tissue samples, 2 sections were placed in a $1.5-\mathrm{ml}$ microcentrifuge tube and $1 \mathrm{ml}$ of $100 \%$ xylene was added. After shaking and vortexing, the tube was heated for $5 \mathrm{~min}$ at $50^{\circ} \mathrm{C}$ to melt the paraffin. The tissue was then pelleted by centrifugation for $2 \mathrm{~min}$ at room temperature at $20,000 \mathrm{~g}$. After centrifugation, the xylene was removed and $1 \mathrm{ml}$ of $100 \% \mathrm{EtOH}$ was added. The sample was mixed and spun by centrifugation again at 20,000 $g$ for $2 \mathrm{~min}$ at room temperature. After centrifugation, the EtOH supernatant was discarded without disturbing the pellet. The ethanol washing process was repeated twice, and during this time as much residual EtOH as possible was removed without disturbing the pellet. Finally, the pellet was air dried for approximately $25 \mathrm{~min}$. Next, an MagNA Pure LC RNA Isolation Kit III (Roche Diagnostics, Mannheim and Penzberg, Germany) was used to isolate RNA from the tissue samples according to the manufacturer's protocol. Briefly, $140 \mu \mathrm{l}$ of homogenization buffer and $16 \mu \mathrm{l}$ of $10 \%$ SDS were added to the deparaffinized tissue. The mixed samples were vortexed and incubated overnight at $55^{\circ} \mathrm{C}$, after which $220 \mu \mathrm{l}$ of tissue lysis buffer was added to the supernatant. A MagNA Pure LC 2.0 (Roche Diagnostics) kit was used to prepare the total RNA. The purity and concentration of the RNA preparations were determined by measuring the absorbance at 260 and $280 \mathrm{~nm}$ using an Infinite $200^{\circledR}$ spectrophotometer (Tecan, Salzburg, Austria). All preparation and handling of the total RNA was conducted in a laminar flow under RNase-free conditions. The isolated RNA was stored at $-70^{\circ} \mathrm{C}$ until use.

\section{Complementary DNA Synthesis}

Complementary DNA (cDNA) was synthesized using an MMLV Reverse Transcriptase Kit (Invitrogen, Carlsbad, Calif., USA) and random hexamers (Invitrogen) according to the manufacturer's recommendations. Briefly, $10 \mu$ lof total RNA was added to a master mix containing $1 \mu \mathrm{l}$ of $10 \mathrm{mM}$ dNTP mix $(10 \mathrm{mM}$ each of dATP, dGTP, dCTP, and dTTP at a neutral pH), $0.25 \mu \mathrm{g}$ of ran-

Clinical Usefulness of a One-Tube Nested

RT-qPCR Assay dom hexamers, and $5 \mu$ of DEPC-treated water in PCR tubes. The reaction mixture was incubated at $65^{\circ} \mathrm{C}$ for $5 \mathrm{~min}$ and then quickly chilled on ice. A mixture of $4 \mu \mathrm{l}$ of $5 \times$ first-strand buffer $[250 \mathrm{mM}$ Tris- $\mathrm{HCl}$ (pH 8.3), $375 \mathrm{mM} \mathrm{KCl}$, and $15 \mathrm{mM} \mathrm{MgCl}_{2}$ ], $2 \mu \mathrm{l}$ of $0.1 \mathrm{M}$ dithiothreitol, and $1 \mu \mathrm{l}$ of M-MLV reverse transcriptase was then added to the previous reaction mixture, and cDNA synthesis was performed via incubations at $25^{\circ} \mathrm{C}$ for $10 \mathrm{~min}, 37^{\circ} \mathrm{C}$ for $50 \mathrm{~min}$, and $70^{\circ} \mathrm{C}$ for $15 \mathrm{~min}$.

\section{Conventional RT-qPCR}

To compare the one-tube nested RT-qPCR assay with conventional RT-qPCR with respect to HER2 mRNA quantification, RTqPCR was used to quantitate HER2 expression as previously described [15]. Amplification reactions were performed on a CFX-96 real-time PCR system (Bio-Rad, Hercules, Calif., USA) under the following conditions: $50^{\circ} \mathrm{C}$ for $2 \mathrm{~min}, 95^{\circ} \mathrm{C}$ for $10 \mathrm{~min}$, and then 40 cycles of $95^{\circ} \mathrm{C}$ for $15 \mathrm{~s}$, and $60^{\circ} \mathrm{C}$ for $1 \mathrm{~min}$.

\section{One-Tube Nested RT-qPCR Assay}

A one-tube nested RT-qPCR assay employing TaqMan probes was used to measure the HER2 mRNA expression levels relative to 3 well-known reference genes, i.e. glyceraldehyde-3-phosphate dehydrogenase (GAPDH), TATA box binding protein (TBP), and $\beta_{2^{-}}$ microglobulin (B2M), which were reported to be the stable genes in several human tissues from breast cancers [16]. Thermocycling and fluorescence detection were performed using a CFX-96 realtime PCR system (Bio-Rad). To detect HER2 mRNA expression, RT-PCR amplification reactions were set up in a total volume of 20 $\mu \mathrm{l}$. Each reaction contained $10 \mu \mathrm{l}$ of $2 \times$ Thunderbird probe qPCR mix (Toyobo, Osaka, Japan), $5 \mu$ of a primer and TaqMan probe mixture (Optipharm, Osong, Republic of Korea), $2 \mu$ l of template cDNA, and $3 \mu \mathrm{l}$ of distilled water. Positive and negative controls were included throughout the procedure. As a negative control, notemplate controls were set up using sterile distilled water instead of template DNA. The thermocycling conditions were as follows: $95^{\circ} \mathrm{C}$ for $3 \mathrm{~min}$, followed first by 10 cycles of $3 \mathrm{~s}$ at $95^{\circ} \mathrm{C}$ and $30 \mathrm{~s}$ at $60^{\circ} \mathrm{C}$ and then by 40 cycles of $3 \mathrm{~s}$ at $95^{\circ} \mathrm{C}$ and $30 \mathrm{~s}$ at $55^{\circ} \mathrm{C}$. The level of mRNA expression was quantified by determining the cycle threshold (Ct), which was defined as the number of PCR cycles required for the fluorescence to exceed a value significantly higher than the background fluorescence. The B2M gene was used as the internal control for RNA quality and to correct for variations in the degree of RNA degradation. The expression level of HER2 relative to GAPDH/TBP/B2M was automatically calculated via the comparative Ct method using CFX Manager Software v1.6 (Bio-Rad). The relative gene expression was assessed using the comparative $\mathrm{Ct}$ $(\Delta \Delta \mathrm{Ct})$ method. In this method, the amount of target transcript is normalized to 1 of 3 internal housekeeping genes (GAPDH, TBP, or B2M), which acts as an internal calibrator. The normalized gene expression is calculated as $2-\Delta \Delta \mathrm{Ct}$, as follows:

$\Delta \Delta \mathrm{Ct}=[\Delta \mathrm{Ct}($ test $)=\mathrm{Ct}($ target test $)-\mathrm{Ct}($ reference test $)]-$ $[\Delta \mathrm{Ct}$ (calibrator) $=\mathrm{Ct}$ (target calibrator) $-\mathrm{Ct}$ (reference calibrator) $]$.

The mRNA expression levels calculated via the $2-\Delta \Delta \mathrm{Ct}$ method represent the mRNA expression levels relative to the given reference gene. A cutoff value of 2.5 for amplification was selected based on a receiver operating characteristic (ROC) curve analysis. HER2 expression was considered amplified in samples in which the HER2 mRNA expression ratio exceeded this threshold in at least 2 of the 3 reference genes. 
Table 1. Detection limits of the one-tube nested RT-qPCR assay as determined using 10-fold serially diluted mRNA from various cell lines

\begin{tabular}{|c|c|c|c|c|}
\hline Cell line & Cells, n & $\begin{array}{l}\text { Mean quantification } \\
\text { cycles, } \mathrm{n}\end{array}$ & $\begin{array}{l}\text { Mean } \\
\text { copies, n }\end{array}$ & $\mathrm{CV}, \%$ \\
\hline BT- 474 & $\begin{array}{l}10^{6} \\
10^{5} \\
10^{4} \\
10^{3} \\
10^{2} \\
10^{1} \\
10^{0}\end{array}$ & $\begin{array}{c}4.1(0.25) \\
8.22(0.19) \\
12.44(0.09) \\
16.74(0.18) \\
20.76(0.3) \\
24.3(0.19) \\
27.85(0.87)\end{array}$ & $\begin{aligned} 1.2(0.21) & \times 10^{11} \\
6.14(0.87) & \times 10^{9} \\
2.92(0.19) & \times 10^{8} \\
1.33(0.17) & \times 10^{7} \\
7.44(1.53) & \times 10^{5} \\
5.74(0.84) & \times 10^{4} \\
5.05(3.09) & \times 10^{3}\end{aligned}$ & $\begin{array}{r}17.6 \\
14.2 \\
6.6 \\
12.9 \\
20.3 \\
14.8 \\
61.1\end{array}$ \\
\hline SK-BR3 & $\begin{array}{l}10^{6} \\
10^{5} \\
10^{4} \\
10^{3} \\
10^{2} \\
10^{1} \\
10^{0}\end{array}$ & $\begin{array}{r}5.19(0.11) \\
9.79(0.53) \\
13.4(0.06) \\
17.43(0.14) \\
21.59(0.43) \\
24.78(0.36) \\
28.69(1.75)\end{array}$ & $\begin{array}{l}5.43(0.45) \times 10^{10} \\
2.07(0.86) \times 10^{9} \\
1.47(0.06) \times 10^{8} \\
8.05(0.81) \times 10^{6} \\
4.15(1.26) \times 10^{5} \\
4.15(1.09) \times 10^{4} \\
3.73(2.29) \times 10^{3}\end{array}$ & $\begin{array}{r}8.4 \\
41.3 \\
4.4 \\
10.1 \\
30.2 \\
26.4 \\
93.7\end{array}$ \\
\hline MDA-MB-231 & $\begin{array}{l}10^{6} \\
10^{5} \\
10^{4} \\
10^{3} \\
10^{2} \\
10^{1}\end{array}$ & $\begin{array}{c}11.3(0.02) \\
14.39(0.19) \\
17.68(0.16) \\
21.87(0.37) \\
25.9(0.21) \\
28.49(1.0)\end{array}$ & $\begin{array}{l}6.64(0.09) \times 10^{8} \\
7.22(0.98) \times 10^{7} \\
6.75(0.79) \times 10^{6} \\
3.37(0.97) \times 10^{5} \\
1.82(0.28) \times 10^{4} \\
3.37(2.64) \times 10^{3}\end{array}$ & $\begin{array}{l}1.5 \\
13.6 \\
11.8 \\
29 \\
15 \\
78.3\end{array}$ \\
\hline MCF-7 & $\begin{array}{l}10^{6} \\
10^{5} \\
10^{4} \\
10^{3} \\
10^{2} \\
10^{1}\end{array}$ & $\begin{array}{l}12.22(0.03) \\
15.32(0.14) \\
18.67(0.11) \\
22.93(0.34) \\
27.04(0.31) \\
30.07(1.37)\end{array}$ & $\begin{array}{l}3.42(0.07) \times 10^{8} \\
3.69(0.4) \times 10^{7} \\
3.29(0.27) \times 10^{6} \\
1.56(0.4) \times 10^{5} \\
8.07(1.8) \times 10^{3} \\
1.27(1.34) \times 10^{3}\end{array}$ & $\begin{array}{r}2.2 \\
10.9 \\
8.4 \\
26.3 \\
22.4 \\
104\end{array}$ \\
\hline
\end{tabular}

Values in parentheses are SD. CV = Coefficient of variation.

\section{Statistical Analysis}

Prism 5 software (GraphPad, La Jolla, Calif., USA) and Statistical Package for the Social Sciences software (version 18.0; SPSS Inc., Chicago, Ill., USA) were used for all statistical analyses. An ROC curve analysis was performed to determine the assay cutoff values for conventional IHC, FISH, and RT-qPCR. To determine the statistical significance of differences between groups, Student's t test and a one-way ANOVA were carried out for 2-group comparisons and multiple-group comparisons, respectively. The association between HER2 expression and clinicopathological features was examined using the $\chi^{2}$ test. $p<0.05$ was considered statistically significant. An IHC score of $3+$ was considered a positive indicator of HER2 expression, whereas scores of 0 and $1+$ were considered negative indicators in all statistical analyses. An IHC score of $2+$ was only considered a positive indicator of HER2 expression if the FISH result was positive.

\section{Results}

\section{Population Characteristics}

The ages of the 226 patients with breast cancer ranged from 26 to 75 years, with a median age of 51 years (SD \pm 10.3 years). Of the 226 FFPE breast cancer tissue samples, $64(28.3 \%), 74(32.7 \%), 42(18.6 \%)$, and $46(20.4 \%)$ had HER2 IHC scores of $3+, 2+, 1+$, and 0 , respectively. A total of 74 HER2 IHC samples were classified as 2+, of which 20 and 54 were found to be HER2 positive and HER2 negative by FISH analysis, respectively. The FFPE samples with IHC scores of $0,1+$, and $3+$ were not confirmed by FISH analysis. The molecular subtypes were determined based on the IHC expression profiles of ER, PR, HER2, and Ki67. These subtypes were modeled according to a modified version of the St. Gallen Interna-
60 
Fig. 1. Relative HER2 mRNA expression levels in BT-474, SK-BR3, MDA-MB 231, and MCF-7 cells as obtained by RT-qPCR. a Relative HER2 mRNA expression levels as detected by one-tube nested RT-qPCR. b Relative HER 2 mRNA expression levels as detected by conventional RT-qPCR.

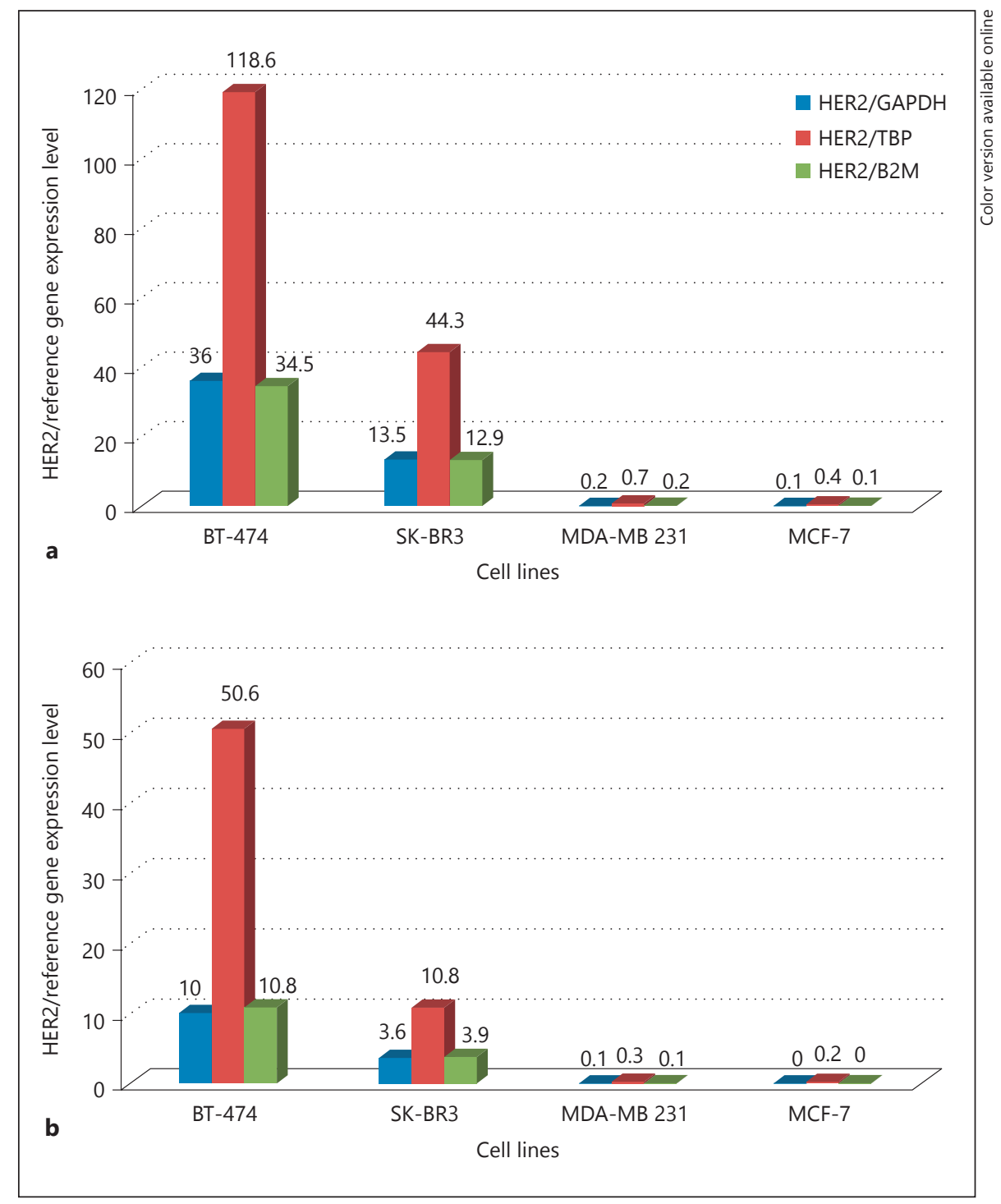

tional Breast Cancer Conference surrogate subtype definition [17]. The subgroup distributions and definitions were as follows: Luminal A ( $\mathrm{n}=47 ; 20.8 \%$; ER+ and/or PR+, HER2-, low Ki67), Luminal B ( $\mathrm{n}=20$; 8.8\%; ER+ and/or PR+, HER2-, high Ki67), Luminal B-HER2-positive $(\mathrm{n}=89 ; 39.4 \%$; ER+ and/or PR+, HER2+, any Ki67), HER2-positive ( $\mathrm{n}=49 ; 21.7 \%$; ER-, PR-, any Ki67), and triple negative ( $\mathrm{n}=21$; 9.3\%; ER-, PR-, HER2-, any Ki67). HER2 mRNA expression relative to 3 reference genes (GAPDH, TBP, and B2M) was examined using an RT-qPCR assay. This assay was initially performed with all 226 FFPE breast cancer tissue samples; considering the quality of the mRNA, samples with reference gene Ct values smaller than 33 were excluded.

Clinical Usefulness of a One-Tube Nested RT-qPCR Assay

\section{Assay Validation}

To determine the analytical detection limit of the onetube nested RT-qPCR HER2 mRNA assay, suspensions of 4 breast cancer cell lines (BT-474, SK-BR3, MCF-7, and MDA-MB-231) were serially diluted 10 -fold from $1 \times 10^{6}$ to $1 \times 10^{0}$ cells $/ \mathrm{ml}$. The analytical sensitivity was estimated as the last serial linear concentration that yielded positive results in all 3 replicates, and the corresponding $\mathrm{Ct}$ value was selected as the analytical cutoff. The overall detection limit of the one-tube nested RTqPCR assay for HER2 expression in the 4 breast cancer cell lines ranged from $10^{1}$ to $10^{0}$ cells $/ \mathrm{ml}$, with the copy number ranging from approximately $1.2(\mathrm{SD} \pm 0.21)$ $\times 10^{11}$ to $1.27(\mathrm{SD} \pm 1.34) \times 10^{3}$ copies $/ \mathrm{ml}$ (table 1$)$. Rela- 
Table 2. Sensitivities and specificities of one-tube nested RT-qPCR HER2 amplifications from the validation set using GAPDH, TBP, $\mathrm{B} 2 \mathrm{M}$, or all 3 reference genes

\begin{tabular}{|c|c|c|c|c|c|c|c|c|c|}
\hline Methods & Genes & $\begin{array}{l}\text { Analyzed } \\
\text { samples, } \mathrm{n}\end{array}$ & $\begin{array}{l}\text { Sensitivity, } \\
\%\end{array}$ & $95 \% \mathrm{CI}$ & $\begin{array}{l}\text { Specificity, } \\
\%\end{array}$ & $95 \% \mathrm{CI}$ & AUC & $95 \% \mathrm{CI}$ & $\mathrm{p}$ \\
\hline \multirow{7}{*}{ qPCR vs. IHC } & HER2/GAPDH & 225 & 96.9 & $0.8916-0.9962$ & 97.7 & $0.9194-0.9972$ & 0.9973 & $0.9934-1.001$ & $<0.0001$ \\
\hline & HER2/TBP & 211 & 87 & $0.7510-0.9463$ & 90.4 & $0.8189-0.9575$ & 0.9547 & $0.9209-0.9885$ & $<0.0001$ \\
\hline & HER2/B2M & 217 & 63.6 & $0.5087-0.7513$ & 66.7 & $0.5429-0.7756$ & 0.6645 & $0.5720-0.7570$ & 0.0009 \\
\hline & HER2/GAPDH + HER2/TBP & 225 & 93.9 & $0.8499-0.9830$ & 97.6 & $0.9166-0.9971$ & 0.9661 & $0.9335-0.9988$ & $<0.0001$ \\
\hline & HER2/GAPDH + HER2/B2M & 225 & 84.6 & $0.7352-0.9237$ & 84.9 & $0.7554-0.9170$ & 0.9335 & $0.8922-0.9747$ & $<0.0001$ \\
\hline & HER2/TBP + HER2/B2M & 217 & 70.8 & $0.5817-0.8140$ & 81 & $0.7092-0.8870$ & 0.8502 & $0.7884-0.9119$ & $<0.0001$ \\
\hline & $\begin{array}{l}\text { HER2/GAPDH + HER2/TBP + } \\
\text { HER2/B2M }\end{array}$ & 225 & 81 & $0.6859-0.9013$ & 90.7 & $0.8249-0.9590$ & 0.9435 & $0.9085-0.9784$ & $<0.0001$ \\
\hline \multirow[t]{7}{*}{ qPCR vs. FISH } & HER2/GAPDH & 225 & 92.4 & $0.8420-0.9716$ & 92.9 & $0.8734-0.9655$ & 0.9801 & $0.9656-0.9945$ & $<0.0001$ \\
\hline & HER2/TBP & 211 & 81.2 & $0.6994-0.8957$ & 83.1 & $0.7683-0.8819$ & 0.9175 & $0.8818-0.9532$ & $<0.0001$ \\
\hline & HER2/B2M & 217 & 60.5 & $0.4934-0.7085$ & 66.9 & $0.5813-0.7492$ & 0.6583 & $0.5821-0.7344$ & $<0.0001$ \\
\hline & HER2/GAPDH + HER2/TBP & 225 & 88 & $0.7844-0.9436$ & 92.1 & $0.8554-0.9633$ & 0.9567 & $0.9282-0.9852$ & $<0.0001$ \\
\hline & HER2/GAPDH + HER2/B2M & 225 & 60.5 & $0.4934-0.7085$ & 72.1 & $0.6138-0.8123$ & 0.6852 & $0.6062-0.7641$ & $<0.0001$ \\
\hline & HER2/TBP + HER2/B2M & 217 & 84.6 & $0.7467-0.9179$ & 86 & $0.7821-0.9176$ & 0.9176 & $0.8763-0.9588$ & $<0.0001$ \\
\hline & $\begin{array}{l}\text { HER2/GAPDH + HER2/TBP + } \\
\text { HER2/B2M }\end{array}$ & 225 & 88.2 & $0.7871-0.9444$ & 92.1 & $0.8554-0.9633$ & 0.9739 & $0.9568-0.9910$ & $<0.0001$ \\
\hline
\end{tabular}

The ROC curve analysis was performed via one-way ANOVA.

tive HER2 mRNA levels were normalized to the HER2 level in MDA-MB-231 cells, which was chosen to represent $1 \times$ the expression of the HER2 gene. In this approach, all mRNA values are expressed as n-fold HER2 mRNA values relative to the calibrator. The BT- 474 and SK-BR3 cell lines, both of which overexpress HER2, exhibited a 118.6- and 44.3-fold higher HER2 expression relative to TBP, a 36- and 13.5-fold higher expression relative to GAPDH, and a 34.5- and 12.9-fold higher expression relative to $\mathrm{B} 2 \mathrm{M}$ compared to $\mathrm{MDA}-\mathrm{MB}-231$ and MCF-7 cells, respectively. To compare the HER2 mRNA one-tube nested RT-qPCR assay with a conventional assay, RT-qPCR was used to quantitate the HER2 mRNA expression levels. Likewise, the HER2/TBP (56.6fold) expression in the BT-474 cell line was higher than the HER2/GAPDH (10-fold) and HER2/B2M (10.6-fold) levels in MDA-MB-231 and MCF-7 cells. However, the levels in SK-BR3 cells were higher than those obtained using the one-tube nested RT-qPCR assay for all 3 reference genes (fig. 1).

\section{Clinical Cutoff Determination and Relative HER2 $m R N A$ Expression Range of the One-Tube Nested RT-qPCR Assay in FFPE Breast Cancer Tissue Clinical Samples}

To determine the range of HER2 mRNA expression according to the IHC score, the relative HER2 mRNA expression levels obtained by the one-tube nested RT-qPCR assay were compared with the HER2 IHC results (fig. 2). The relative HER2/GAPDH mRNA expression levels in the IHC $3+, 2+/ \mathrm{FISH}+, 2+/ \mathrm{FISH}-, 1+$, and 0 samples were
2.3-316.5 (SD \pm 50.5 ), 3.1-66.8 (SD \pm 20.7 ), 0.5-15.3 (SD $\pm 3.0), 0.5-3.3(\mathrm{SD} \pm 0.6)$, and $0.1-2.4(\mathrm{SD} \pm 0.6)$, respectively. The HER2/TBP mRNA expression levels in the HER2 IHC 3+, 2+/FISH+, 2+/FISH-, 1+, and 0 groups were 0.3-191.3 (SD \pm 37.5 ), 0.9-189.6 ( $\mathrm{SD} \pm 46.4$ ), 0.0712.7 (SD \pm 2.8 ), 0.2-14.52 (SD \pm 2.7 ), and $0.2-4.1$ (SD \pm 0.9 ), respectively. The HER2/B2M mRNA expression levels in the HER2 IHC 3+, 2+/FISH+, 2+/FISH-, 1+, and 0 groups were $0.04-176.06$ ( $\mathrm{SD} \pm 33.5$ ), $0.17-16.6$ (SD $\pm 3.8), 0.0-17.0(\mathrm{SD} \pm 3.3), 0.1-9.8(\mathrm{SD} \pm 2.7)$, and $0.1-$ $15.6(\mathrm{SD} \pm 2.9)$, respectively.

To determine the optimal diagnostic cutoff value of the assay, an ROC curve analysis was performed. For this analysis, HER2 IHC 3+ and IHC 2+/FISH+ samples were included as positive controls, HER2 IHC 0 and $1+$ samples were included as negative controls, and HER2 IHC 2+/FISH- samples were excluded due to HER2 expression discrepancies between IHC and FISH. The cutoff HER2 mRNA expression level for the HER2 RT-qPCR assay was determined to be 2.2. The ROC curve analysis revealed that the HER2/GAPDH cutoff had a sensitivity of $96.9 \%$ and a specificity of $97.7 \%$ [area under the curve (AUC) 0.9973 ; 95\% CI $0.9934-1.001, \mathrm{p}<0.0001]$, the HER2/TBP cutoff had a sensitivity of $87 \%$ and a specificity of $90.4 \%$ (AUC 0.9547 ; 95\% CI $0.9209-0.9885$, p < 0.0001 ), and the HER2/B2M cutoff had a sensitivity of $63.6 \%$ and a specificity of $66.7 \%$ (AUC 0.6645 ; 95\% CI $0.5720-0.7570, \mathrm{p}=0.0009$; table 2 ). Using only a single gene, we were able to achieve sensitivities ranging from 63.6 to $96.9 \%$ (of particular note, $96.9 \%$ sensitivity was achieved with HER2/GAPDH). However, the sensitivity 


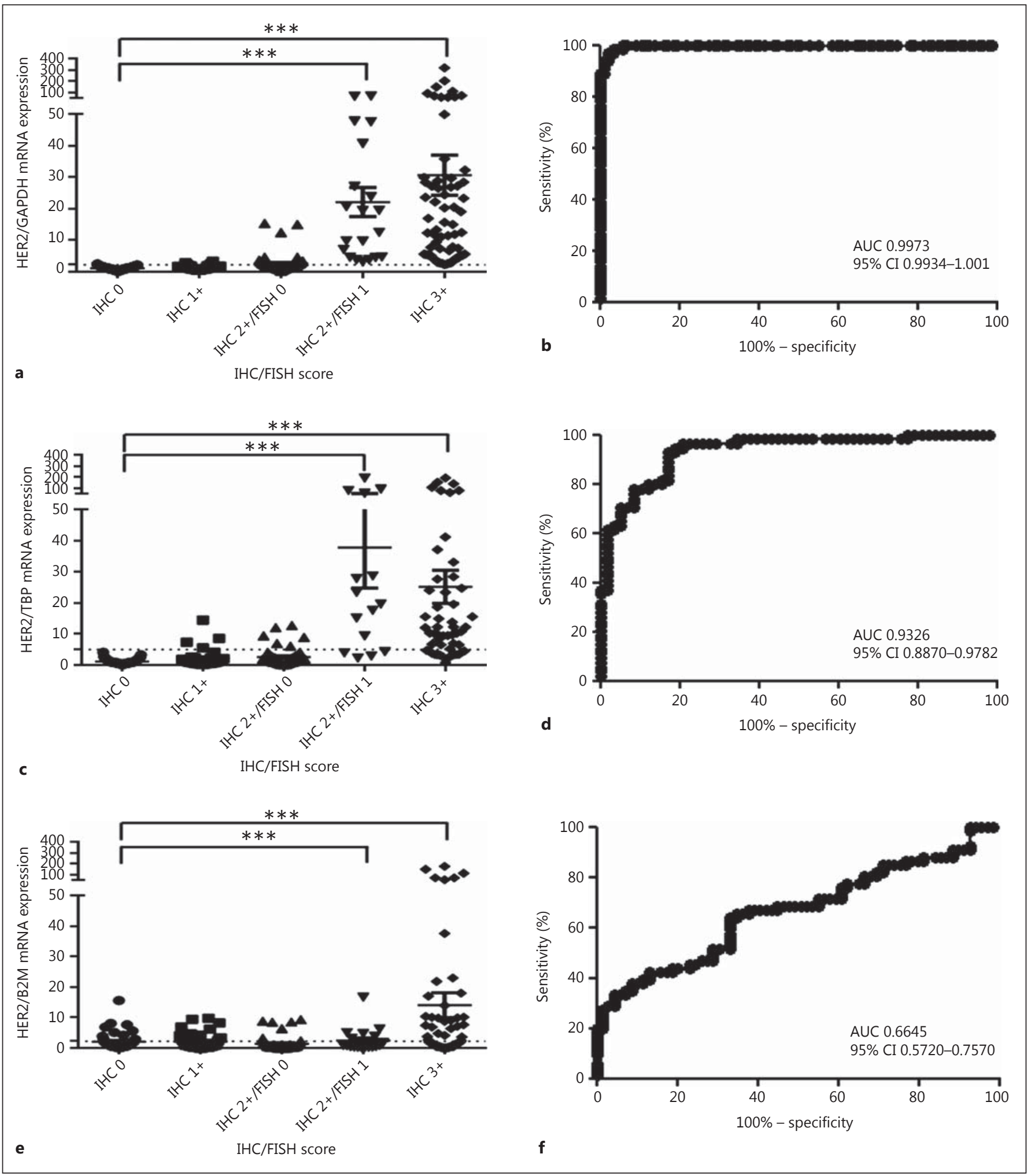

Fig. 2. Cutoff determination and ROC curves of HER2/reference gene ratios in FFPE breast cancer samples in the validation set. The values obtained with the one-tube nested RT-qPCR assay were compared with the values obtained using the gold-standard meth- ods IHC and FISH (HER2/CEP17 ratio). The ROC curve for each of the 3 reference genes is shown separately. a, b GAPDH. c, d TBP. e, f B2M. One-way ANOVA analysis of one-tube nested RT-qPCR data compared to IHC and FISH data $(* * * \mathrm{p}<0.0001)$. 


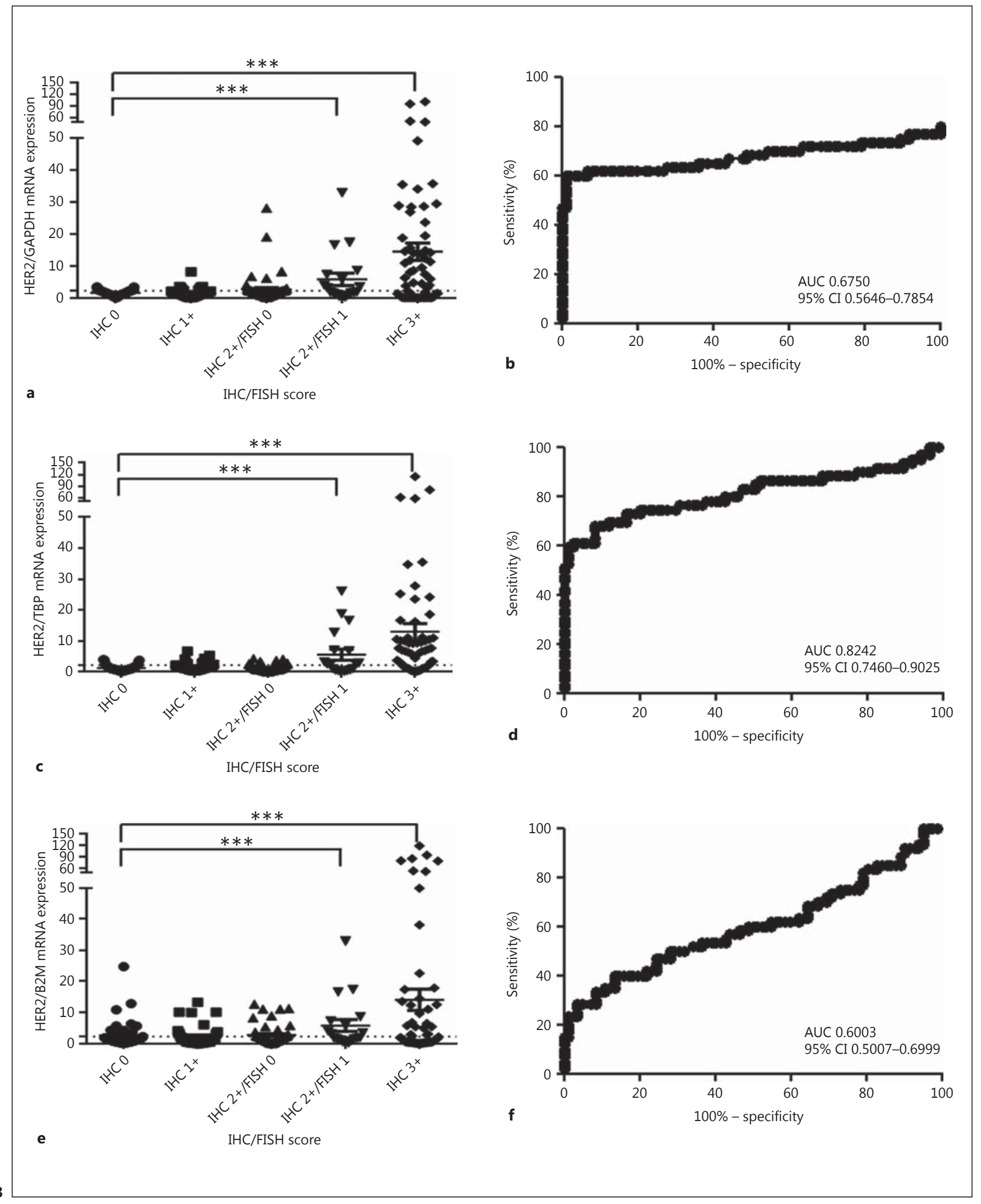

(For legend see next page.) 
Table 3. Comparison of the one-tube nested RT-qPCR assay with IHC/FISH for the detection of HER2 overexpression

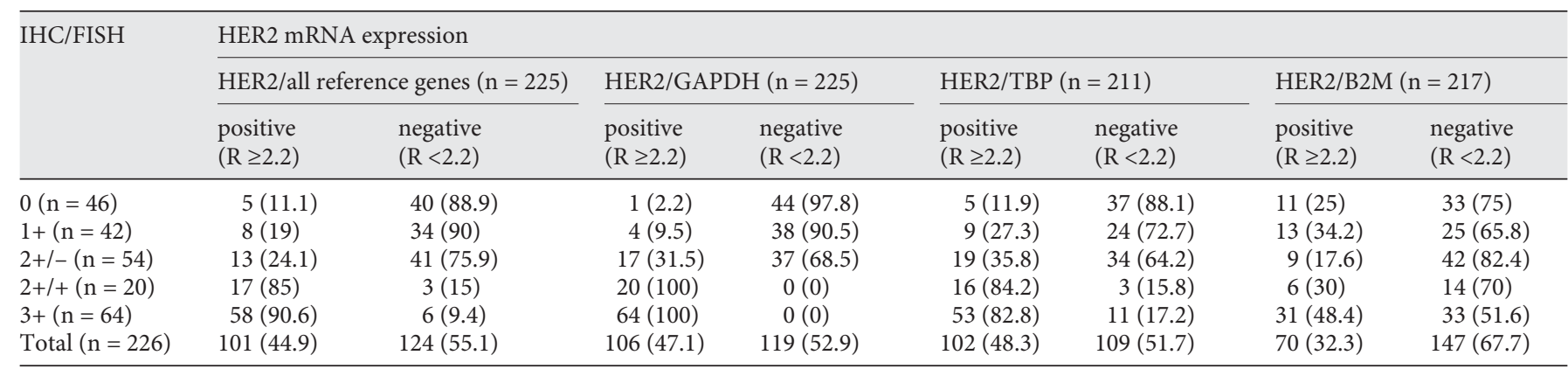

Values are presented as numbers of samples (\%). One sample with an IHC score of 0 was not amplified with the 3 reference genes and is excluded from these results.

was not substantially improved by using combinations of 2 (from 70.8 to $93.9 \%$ ) or 3 (81\%) reference genes.

Additionally, the relative HER2 mRNA expression levels obtained by conventional RT-qPCR were compared to those obtained using the one-tube nested RTqPCR assay (fig. 3). The ROC curve analysis revealed that the HER2/GAPDH approach yielded a sensitivity of $61.7 \%$ and a specificity of $93 \%$ (AUC $0.6750 ; 95 \%$ CI $0.5646-0.7854, \mathrm{p}<0.001)$, the HER2/TBP approach had a sensitivity of $72.9 \%$ and a specificity of $86.7 \%$ (AUC 0.8242 ; $95 \%$ CI $0.7460-0.9025, \mathrm{p}<0.0001$ ), and the HER $2 /$ B2M approach had a sensitivity of $51.7 \%$ and a specificity of 65.9\% (AUC 0.6003; 95\% CI 0.5007-0.6999, p < 0.05).

\section{Comparison between the One-Tube Nested RT-qPCR} and IHC Assays

Considering the quality of mRNA, 225 (99.6\%) HER2/ GAPDH, 211 (93.4\%) HER2/TBP, and 217 (96.0\%) HER2/B2M samples out of a total of 226 samples were analyzed. IHC analysis yielded negative indications (scores of 0 or $1+$ ) for 88 of the 226 tested samples (38.9\%). Of these 88, $82(93.2 \%), 61(69.3 \%)$, and 58 (65.9\%) were qPCR negative by HER2/GAPDH, HER2/ TBP, and HER2/B2M measurements, respectively. An

Fig. 3. Cutoff determination and ROC curves of HER2/reference gene ratios in FFPE breast cancer samples in the validation set. The values obtained using conventional RT-qPCR were compared with the values obtained using the gold standards IHC and FISH (HER2/CEP17 ratio). The ROC curve for each of the 3 reference genes is shown separately. a, b GAPDH. c, dTBP. e, f B2M. HER2/ reference ratios $>2.2$ and $<2.2$ were considered positive and negative for overexpression, respectively. One-way ANOVA analysis of one-tube nested RT-qPCR data compared to IHC and FISH data $(* * * \mathrm{p}<0.0001)$.

Clinical Usefulness of a One-Tube Nested RT-qPCR Assay equivocal IHC $2+$ score was obtained for 74 samples (32.7\%). Of these 74 IHC $2+$ specimens, 37 (50\%), 35 (47.3\%), and 15 (20.3\%) were RT-qPCR negative by HER2/GAPDH, HER2/TBP, and HER2/B2M, respectively. Strong IHC positivity ( $3+$ ) was detected in 64 of the tested samples (28.3\%). The RT-qPCR assay yielded positive results for $64(100 \%), 53(82.8 \%)$, and $31(48.4 \%)$ samples by HER2/GAPDH, HER2/TBP, and HER2/B2M, respectively (table 3 ).

\section{Comparison of the One-Tube Nested RT-qPCR and \\ FISH Assays}

A total of $79(35 \%)$ ambiguous cases of HER2 IHC (score of $2+$ ) were reconfirmed via HER2 FISH assay. Among the 20 HER2 IHC 2+/FISH+ FFPE tissue samples, $20(100 \%)$ and $0(0 \%), 16(80 \%)$ and $3(15 \%)$, and 6 (30\%) and $14(70 \%)$ cases were found to be positive (relative HER2 mRNA expression level $\geq 2.2$ ) and negative (relative HER2 mRNA expression level $<2.2$ ) by HER2/ GAPDH, HER2/TBP, and HER2/B2M RT-qPCR assays, respectively. One HER2/TBP case could not be amplified. Likewise, among the 54 HER2 IHC 2+/FISH- cases, 17 (31.5\%) and 37 (68.5\%), 19 (35.8\%) and 34 (64.2\%), and $9(17.6 \%)$ and $42(82.4 \%)$ cases were found to be positive and negative via HER2/GAPDH, HER2/TBP, and HER2/ B2M RT-qPCR assay, respectively. One HER2/TBP and 2 HER2/B2M cases could not be amplified via RT-qPCR assay (table 3).

\section{Comparison of the One-Tube Nested RT-qPCR and}

Conventional RT-qPCR Assays Using Clinical Samples

To determine the diagnostic potential of the one-tube nested RT-qPCR assay in clinical samples, the results of this assay were compared with previously reported HER2 levels obtained by conventional RT-qPCR [15]. Of the 
Table 4. Comparison of the one-tube nested RT-qPCR and conventional RT-qPCR assays using results from FFPE breast cancer samples

\begin{tabular}{|c|c|c|c|c|c|c|c|c|}
\hline \multirow[t]{2}{*}{ HER2/reference gene } & \multicolumn{4}{|c|}{ One-tube nested RT-qPCR } & \multicolumn{4}{|c|}{ Conventional RT-qPCR } \\
\hline & $\begin{array}{l}\text { sensitivity, } \\
\mathrm{n}(\%)\end{array}$ & $95 \% \mathrm{CI}$ & $\begin{array}{l}\text { specificity, } \\
\text { n (\%) }\end{array}$ & $95 \% \mathrm{CI}$ & $\begin{array}{l}\text { sensitivity, } \\
\mathrm{n}(\%)\end{array}$ & $95 \% \mathrm{CI}$ & $\begin{array}{l}\text { specificity, } \\
\text { n (\%) }\end{array}$ & $95 \% \mathrm{CI}$ \\
\hline HER2/GAPDH $(\mathrm{n}=171)$ & $84(100)$ & $0.9625-1$ & $82(94.3)$ & $0.8693-0.9784$ & $50(59.5)$ & $0.4883-0.6939$ & $70(80.5)$ & $0.7082-0.8752$ \\
\hline HER2/TBP $(\mathrm{n}=158)$ & $69(82.1)$ & $0.7249-0.8898$ & $61(81.3)$ & $0.7095-0.8867$ & $55(65.5)$ & $0.5481-0.7479$ & $61(81.3)$ & $0.7095-0.8867$ \\
\hline HER2/B2M $(n=166)$ & $37(44)$ & $0.3392-0.5470$ & $58(70.7)$ & $0.6009-0.7952$ & $31(36.9)$ & $0.2735-0.4760$ & $61(74.4)$ & $0.6394-0.8266$ \\
\hline
\end{tabular}

171 FFPE tissue samples, 84 were HER2 positive (IHC 3+ or FISH positive) and 45 were HER 2 negative (IHC 0 or $1+)$. The sensitivities of the one-tube nested RT-qPCR and conventional RT-qPCR assays were $100 \%(\mathrm{n}=84$; 95\% CI $0.9625-1.0)$ and $59.5 \%(\mathrm{n}=50$; $95 \%$ CI $0.4883-$ $0.6939)$ for HER2/GAPDH, 82.1\% $(\mathrm{n}=69 ; 95 \% \mathrm{CI}$ $0.7249-0.8898)$ and $65.5 \%(\mathrm{n}=55 ; 95 \%$ CI $0.5481-0.7479)$ for HER2/TBP, and $44 \%(\mathrm{n}=37 ; 95 \%$ CI $0.3392-0.5470)$ and $36.9 \%(\mathrm{n}=31$; 95\% CI $0.2735-0.4760)$ for HER2/ $\mathrm{B} 2 \mathrm{M}$, respectively (table 4). The specificities of the onetube nested RT-qPCR and conventional RT-qPCR assays were $94.3 \%(\mathrm{n}=82$; $95 \%$ CI $0.8693-0.9784)$ and $80.5 \%$ ( $\mathrm{n}=70$; 95\% CI 0.7082-0.8752) for HER2/GAPDH, 81.3 and $81.3 \%(\mathrm{n}=61 ; 95 \%$ CI $0.7095-0.8867)$ for HER2/ TBP, and 70.7\% ( $\mathrm{n}=58$; 95\% CI 0.6009-0.7952) and $74.4 \%$ ( $\mathrm{n}=61 ; 95 \%$ CI $0.6394-0.8266)$ for HER2/B2M, respectively (table 4 ).

\section{Associations between HER2 mRNA Expression and}

Clinicopathological Characteristics in Patients with

Breast Cancer

The associations between HER2 expression and other clinicopathological parameters were analyzed using the $\chi^{2}$ test for different groups of patients with breast cancer. No statistically significant associations were observed between HER2 expression and lymph node invasion status $(\mathrm{p}=0.078)$, histological grade $(\mathrm{p}=0.489), \mathrm{AR}(\mathrm{p}=0.061)$ and Ki67 ( $\mathrm{p}=0.402)$ IHC status, or chemotherapy ( $\mathrm{p}=$ $0.110)$. However, HER2 expression was significantly correlated with age $(\mathrm{p}<0.05)$, TNM stage $(\mathrm{p}<0.01)$, histological type $(\mathrm{p}<0.01)$, estrogen receptor $(\mathrm{ER})$ status $(\mathrm{p}<$ $0.001)$, progesterone receptor $(\mathrm{PR})$ status $(\mathrm{p}<0.05)$, HER2 status ( $\mathrm{p}<0.001)$, and molecular subtype $(\mathrm{p}<$ 0.001 ; table 5$)$.

\section{Discussion}

HER2 expression has become widely accepted as a prognostic and predictive marker in clinical breast cancer, making this receptor a valuable target for the treat- ment of patients with breast cancer [18]. HER2 overexpression was known to have a significantly better response to adjuvant-based chemotherapy before the trastuzumab era [19]. The optimal therapy choice for patients with breast cancer depends on the HER2 status. Proper classification of HER2-positive breast cancer is a prerequisite for deciding which patients should receive trastuzumab, particularly when considering patients with breast cancer treated with both traditional chemotherapy and hormonal therapy. Although trastuzumab treatment is beneficial for advanced breast cancer, it should be given carefully to avoid potential cardiotoxic effects in women who do not show amplification or overexpression [20]. Therefore, the high cost and side effects of trastuzumab therapy necessitate highly accurate, robust, sensitive, and cost-effective testing protocols to evaluate HER2 expression in a clinical setting [20]. IHC and FISH analysis have been approved by the FDA and are the assays most commonly used to determine the HER2 status in the clinical setting. IHC staining is predominantly used to evaluate HER2 status because this technique is easy to perform and has a relatively low cost. However, the sensitivity and specificity of this technique vary greatly according to the particular commercially available antibody used. Thus, IHC-ambiguous HER2+ cases are submitted to other tests such as FISH [14]. FISH is considered the secondline method for weakly positive samples with an IHC score of $2+$. The advantage of FISH is that quantitative interpretation of the results is relatively straightforward for experienced personnel, with concordance rates among observers higher than those found with IHC [18]. However, in approximately $5 \%$ of all breast cancer samples, HER2 copy numbers cannot be evaluated by FISH because of poor tissue quality. This setback may be due to incorrect handling, especially in cases in which inappropriate fixation or degradation has occurred [21]. Moreover, these methods can only determine the HER2 status at the time of diagnosis, and the HER2 status of tumor samples in patients with recurrent or metastatic breast cancer cannot always be determined. It would be useful to monitor patients during follow-up to determine wheth- 
er they are responding to trastuzumab therapy [22]. RTqPCR is a powerful technique to confirm HER2 gene expression differences or measure transcript abundance. The specific advantages of RT-qPCR include its sensitivity, reproducibility, simplicity, and high-throughput capabilities. Moreover, the speed and ease of PCR-based testing enable rapid screening of multiple samples. Furthermore, the development of fluorescence-based realtime monitoring has enabled PCR to be a quantitative method. To reduce possible errors, PCR amplification and quantification are performed in the same reaction tube. Due to its high sensitivity, nested RT-qPCR has been proposed to be an excellent method for determining the HER2 status [23]. The HER2 mRNA expression assay proposed here has a one-tube nested RT-qPCR design that is approximately 100 times more sensitive than conventional qPCR. Our results are consistent with previous reports indicating that nested PCR exhibits a greatly enhanced sensitivity compared to conventional PCR, probably because of the 2 sequential amplification steps of the target gene. In addition, one-tube nested qPCR has the same advantages of conventional qPCR, including speed, accuracy, a low risk of cross-contamination, and ease [23]. In this study, 3 widely used reference genes were chosen to detect variation of HER2 gene expression [16]. The Ct variations of the reference genes were a little high, with the coefficients of variation ranging from 3 to $7 \%$. Unlike in a previous report stating that GAPDH was not the most stable reference gene [16], we found that the HER2/GAPDH combination $(96.9 \%$ sensitivity and 97.7\% specificity) was superior to HER2/TBP ( $87 \%$ sensitivity and $90.4 \%$ specificity) and HER2/B2M (63.6\% sensitivity and $66.7 \%$ specificity). Also, the sensitivity and specificity of the HER2/GAPDH combination did not improve substantially when combinations of 2 (from 70.8 to $93.9 \%)$ or $3(81 \%)$ reference genes were used. These results differ from those of previous studies reporting a superior sensitivity with combinations of 2 or 3 reference genes [24]. However, single RT-qPCR with 2 or 3 reference genes exhibited increased sensitivity (from 63.5 to $74.6 \%)$ compared to the same assay with a single reference gene (51.7-71.2\%). Since the one-tube nested RTqPCR assay already exhibited improved sensitivity compared to single RT-qPCR, we may not have been able to improve this sensitivity by adding reference genes. Also, we found that the choice of optimal reference genes was important for determining the expression level of HER2. Due to their low specificity, TBP and B2M are inadequate as reference genes for determining the HER2 status using one-tube nested RT-qPCR.
Table 5. Associations between HER 2 mRNA expression levels obtained by one-tube nested RT-qPCR and clinicopathological features

\begin{tabular}{|c|c|c|c|c|}
\hline & \multirow[t]{2}{*}{$\mathrm{n}$} & \multicolumn{3}{|c|}{$\begin{array}{l}\text { HER2 expression by one-tube nested } \\
\text { RT-qPCR }\end{array}$} \\
\hline & & positive, $\mathrm{n}(\%)$ & negative, n (\%) & $\mathrm{p}$ \\
\hline \multicolumn{5}{|l|}{ Age } \\
\hline$<40$ years & 21 & $4(19)$ & $17(81)$ & $<0.05$ \\
\hline $40-59$ years & 143 & $63(44.1)$ & $80(55.9)$ & \\
\hline$\geq 60$ years & 48 & $25(52.1)$ & $23(47.9)$ & \\
\hline \multicolumn{5}{|l|}{ TNM stage } \\
\hline $0 / 1$ & 77 & $20(26)$ & $27(74)$ & $<0.01$ \\
\hline 2 & 49 & $14(28.6)$ & $35(71.4)$ & \\
\hline 3 & 14 & $10(71.4)$ & $4(28.6)$ & \\
\hline 4 & 5 & $3(60)$ & $2(40)$ & \\
\hline \multicolumn{5}{|l|}{ Histological grade } \\
\hline 1 & 28 & $4(14.3)$ & $24(85.7)$ & 0.489 \\
\hline 2 & 53 & $13(24.5)$ & $40(75.5)$ & \\
\hline 3 & 39 & $10(25.6)$ & $29(74.4)$ & \\
\hline \multicolumn{5}{|l|}{ Histological type } \\
\hline Ductal carcinoma & 177 & 79 (44.6) & $98(55.4)$ & 0.904 \\
\hline IDCA & 161 & $64(39.8)$ & $97(60.2)$ & \\
\hline DCIS & 16 & $15(93.8)$ & $1(6.3)$ & \\
\hline Lobular carcinoma & 13 & $3(42.9)$ & $4(57.1)$ & \\
\hline ILC & 8 & $4(50)$ & $4(50)$ & \\
\hline Tubular adenocarcinoma & 5 & $1(20)$ & $4(80)$ & \\
\hline Other & 7 & $3(42.9)$ & $4(57.1)$ & \\
\hline \multicolumn{5}{|l|}{ Therapy } \\
\hline Adjuvant & 108 & $26(24.3)$ & $81(75.7)$ & 0.11 \\
\hline Neoadjuvant & 25 & $4(16)$ & $21(84)$ & \\
\hline Metastasis & 5 & $3(60)$ & $2(40)$ & \\
\hline \multicolumn{5}{|l|}{ Lymph node invasion status } \\
\hline Negative & 96 & $21(21.9)$ & $75(78.1)$ & 0.078 \\
\hline Positive & 35 & $9(25.7)$ & $26(74.3)$ & \\
\hline \multicolumn{5}{|l|}{$I H C$} \\
\hline ER positive & 153 & $59(38.6)$ & $94(61.4)$ & $<0.001$ \\
\hline ER negative & 73 & $47(64.4)$ & $26(35.6)$ & \\
\hline PR positive & 93 & $34(36.6)$ & $59(63.4)$ & $<0.05$ \\
\hline PR negative & 133 & $72(54.1)$ & $61(45.9)$ & \\
\hline HER2 positive & 138 & $101(73.2)$ & $37(26.8)$ & $<0.001$ \\
\hline HER2 negative & 88 & $5(5.7)$ & $83(94.3)$ & \\
\hline AR positive & 77 & $20(26)$ & $57(74)$ & 0.061 \\
\hline AR negative & 78 & $32(41)$ & $46(59)$ & \\
\hline Ki67 positive & 100 & $46(46)$ & $54(39.8)$ & 0.402 \\
\hline Ki67 negative & 108 & $43(54)$ & $65(60.2)$ & \\
\hline \multicolumn{5}{|l|}{ Molecular subtype } \\
\hline Luminal A & 47 & $4(8.5)$ & $43(91.5)$ & $<0.001$ \\
\hline Luminal B & 20 & $1(5)$ & $19(95)$ & \\
\hline \multicolumn{5}{|l|}{ Luminal B } \\
\hline HER2 positive & 89 & $57(64)$ & $32(36)$ & \\
\hline HER2 negative & 49 & $44(89.9)$ & $5(10.2)$ & \\
\hline TNBC & 21 & $0(0)$ & $21(100)$ & \\
\hline
\end{tabular}

IDCA = Invasive ductal breast carcinoma; DCIS = ductal carcinoma in situ; ILC = infiltrating (invasive) lobular carcinoma; $\mathrm{AR}=$ androgen receptor; $\mathrm{TNBC}=$ triple-negative breast cancer. $\mathrm{p}$ values were determined by the $\chi^{2}$ test. 
To investigate the relationships between DNA, mRNA, and protein levels in breast tumors, we compared the results obtained via FISH, RT-qPCR, and IHC. Numerous studies have used RT-PCR to assess HER2 DNA or mRNA expression. In general, the overall concordance rates between RT-PCR and IHC range from 72.7 to $93 \%[15,25]$. Similarly, the concordance rates in the present study between IHC and our one-tube nested RT-qPCR assay were 82/87 (94.3\%) and 64/64 (100\%) for IHC 0/1+ and IHC 3+ samples, respectively. HER2 expression levels in IHC $3+$ samples were higher $(\mathrm{p}<0.01)$ than those observed in negative samples (IHC 0 and IHC 1+), with a median difference in expression levels of 1.3. Our one-tube nested RTqPCR assay proved to be highly sensitive and specific based on comparisons with IHC data (96.9 and $97.7 \%$, respectively) and FISH data ( 92.4 and $92.9 \%$, respectively) obtained with the validation set. The overall sensitivity, specificity, positive predictive value, and negative predictive value of our one-tube nested RT-qPCR assay with the IHC data were $100 \%(\mathrm{n}=64 ; 95 \%$ CI $0.9513-1.0), 94.3 \%$ $(\mathrm{n}=82 ;$; $95 \%$ CI $0.8693-0.9784), 94.8 \%$ (95\% CI 0.8720 0.9789 ), and $100 \%$ (95\% CI $0.9616-1.0$ ), respectively. The sensitivity (100\%) and specificity (94.3\%) of this assay were higher than those of previously reported studies $(80 \%$ to $91 \%$ ) and of the conventional RT-qPCR results in this study, which had a sensitivity of 59.5\% (95\% CI $0.4883-$ 0.6939 ), a specificity of $80.4 \%$ ( $95 \%$ CI $0.7082-0.8752$ ), a positive predictive value of $74.6 \%$ (95\% CI $0.6299-0.8359$ ), and a negative predictive value of $67.3 \%$ (95\% CI 0.5780 $0.7559)$, respectively. We also found that FISH-positive tumors showed higher HER2 expression levels than FISHnegative breast tumors $(\mathrm{p}<0.001)$. Most FISH-positive tumors exhibited significant HER2 mRNA overexpression, with relative expression values ranging from 3.1 to 66.8 and a median of 22.1 ( $S D \pm 20.7$ ). This finding reflects the probable relationship between DNA and RNA expression levels. The overall sensitivity and specificity of this assay compared to FISH were 100 and $68.5 \%$. The low specificity is probably because 17 (31.5\%) of the 54 HER2 IHC 2+/FISH- cases showed HER2 mRNA overexpression, with relative values ranging from 2.4 to 15.3 (5.1 \pm 4.45). Moreover, 16 of these cases were also found to be HER2 positive by conventional RT-qPCR. Further studies are needed to determine whether these patients would benefit from trastuzumab therapy. We propose that the 17 FISH-negative cases with a high HER2 mRNA expression as measured by RT-qPCR should be categorized as probably therapeutically and prognostically related to geneamplified tumors. This classification provides the opportunity to choose trastuzumab therapy if appropriate. We propose a similar classification for patients with IHC $2+$ / FISH-positive results [15]. FISH is not routinely performed in small hospitals or other similar settings due to its high cost and the need for specialized equipment and facilities. These drawbacks have been proposed as the primary reasons why FISH is not widely used [25]. Our FISH data revealed that only 74 samples had an IHC score of $2+$; additional tests with more samples are needed to fully compare the results obtained with our method to those obtained with FISH. Nevertheless, our one-tube nested RT-qPCR assay is complementary to FISH due to the significant correlations with existing standard diagnostic approaches demonstrated here. We did not observe any correlations between HER2 expression status as measured by IHC or gene copy and any of the clinicopharmacological data, including lymph node status, histological grade, and Ki67 status. Similarly, the absence of correlations between HER2 status and clinical and pathological features has been reported in other studies [26,27].

Additionally, HER2 overexpression in patients with breast cancer is generally analyzed in primary tumors; however, HER2 analysis in the blood may also have a clinical significance for HER2-targeted therapy. This is because tumor cells delivered from the primary tumor or secondary sites into the bloodstream do not always share genetic characteristics and can be detected in patients with HER2-negative primary tumors [28]. In a pilot study, an RT-qPCR assay was performed on 138 blood samples from the same patients with breast cancer from whom FFPE tissue samples were obtained. This pairing allowed us to investigate the association of HER2 mRNA expression in FFPE tissue and blood samples. Among the 138 blood samples, 45 (32.6\%) cases were HER2 positive, and 27 of these were also HER 2 positive based on FFPE tissue samples. Importantly, 18 (13\%) patients with breast cancer who were classified as HER2 negative by IHC were classified as HER2 positive by RT-qPCR. These patients did not have access to trastuzumab-based therapy at the time of writing. Therefore, assessment of circulating tumor cells for HER2 overexpression could potentially help to identify patients who would not otherwise be considered candidates for HER2-targeted therapy because of their negative disease status. Also, we found that HER2 mRNA expression levels in blood samples can be quite different from those in the primary tumor, although this difference was not significant (Pearson's $r=0.005, p=0.955$; data not shown). This finding is consistent with a previous result reporting concordance in HER2 amplification between the primary and secondary tumors of patients with breast cancer, but discordance in the HER2 transcript lev- 
els in the primary tumors and circulating tumor cells [29]. However, it is necessary to obtain more data confirming that the HER2 mRNA value in peripheral blood samples is really derived from HER2-overexpressing cancer cells via basic experiments such as acquisition of clinical data in patients with breast cancer relapse stratified by the HER2 status of the primary breast cancer.

In conclusion, our data indicate that the one-tube nested RT-qPCR assay to detect HER2 mRNA overex- pression can be a potentially useful and complementary screening method for FFPE tissue samples. We propose that our one-tube nested RT-qPCR assay will provide useful information to predict the effects of trastuzumab therapy in patients with breast cancer. Moreover, our assay can be used as a diagnostic tool when primary tumor samples are unavailable or to monitor disease outcomes and therapy responses during follow-up of patients with breast cancer.

\section{References}

1 Stewart BW, Wild CP: World Cancer Report 2014: WHO cancer factsheet No 297. 2015. http://www.who.int/mediacentre/factsheets/fs297/en/index.html (accessed April 2012).

2 Jung KW, Won YJ, Kong HJ, Oh CM, Seo HG, Lee JS: Cancer statistics in Korea: incidence, mortality, survival and prevalence in 2011. Cancer Res Treat 2014;46:109-123.

3 Rosa FE, Silveira SM, Silveira CG, Bérgamo NA, Neto FA, Domingues MA, Soares FA, Caldeira JR, Rogatto SR: Quantitative realtime RT-PCR and chromogenic in situ hybridization: precise methods to detect HER-2 status in breast carcinoma. BMC Cancer 2009;9:90.

4 Slamon DJ, Clark GM, Wong SG, Levin WJ, Ullrich A, McGuire WJ: Human breast cancer: correlation of relapse and survival with amplification of the HER-2/neu oncogene. Science 1987;235:177-182.

5 Hall PS, Hulme C, McCabe C, Oluboyede Y, Round J, Cameron DA: Updated cost-effectiveness analysis of trastuzumab for early breast cancer: a UK perspective considering duration of benefit, long-term toxicity and pattern of recurrence. Pharmacoeconomics 2011;29:415-432.

6 Hillner BE, Smith TJ: Do the large benefits justify the large costs of adjuvant breast cancer trastuzumab? J Clin Oncol 2007;25:611613.

7 Levy A, Borget I, Bahri M, Arnedos M, Rivin E, Vielh P, Balleyguier C, Rimareix F, Bourgier C: Loco-regional control after neo-adjuvant chemotherapy and conservative treatment for locally advanced breast cancer patients. Breast J 2014;20:381-387.

8 Sendur MA, Aksoy S, Altundag K: Cardiotoxicity of novel HER2-targeted therapies. Curr Med Res Opin 2014;29:1015-1024.

9 Jacquemier J, Spyratos F, Esterni B, Mozziconacci MJ, Antoine M, Arnould L, Lizard S, Bertheau P, Lehmann-Che J, Fournier CB, Krieger S, Bibeau F, Lamy PJ, Chenard MP, Legrain $M$, Guinebretière JM, Loussouarn D,
Macgrogan G, Hostein I, Mathieu MC, Lacroix L, Valent A, Robin YM, Revillion F, Triki ML, Seaume A, Salomon AV, de Cremoux P, Portefaix G, Xerri L, Vacher S, Bièche I, Penault-Llorca F: SISH/CISH or qPCR as alternative techniques to FISH for determination of HER2 amplification status on breast tumors core needle biopsies: a multicenter experience based on 840 cases. BMC Cancer 2013;13:351.

10 Arnould L, Roger P, Macgrogan G, Chenard MP, Balaton A, Beauclair S, Penault-Llorca F: Accuracy of HER2 status determination on breast core-needle biopsies (immunohistochemistry, FISH, CISH and SISH vs FISH). Mod Pathol 2012;25:675-682.

11 Odicino FE, Bignotti E, Rossi E, Pasinetti B, Tassi RA, Donzelli C, Falchetti M, Fontana P, Grigolato PG, Pecorelli S: HER-2/neu overexpression and amplification in uterine serous papillary carcinoma: comparative analysis of immunohistochemistry, real-time reverse transcription-polymerase chain reaction, and fluorescence in situ hybridization. Int J Gynecol Cancer 2008; 18:14-21.

12 Sauter G, Lee J, Bartlett JMS, Slamon DJ, Press MF: Guidelines for human epidermal growth factor receptor 2 testing: biologic and methodologic considerations. J Clin Oncol 2009; 27:1323-1333.

13 Gutierrez C, Schiff R: HER2: biology, detection, and clinical implications. Arch Pathol Lab Med 2011;135:55-62.

14 Wolff AC, Hammond ME, Hicks DG, Dowsett M, McShane LM, Allison KH, Allred DC, Bartlett JM, Bilous M, Fitzgibbons P, Hanna W, Jenkins RB, Mangu PB, Paik S, Perez EA, Press MF, Spears PA, Vance GH, Viale G, Hayes DF; American Society of Clinical Oncology; College of American Pathologists: Recommendations for human epidermal growth factor receptor 2 testing in breast cancer: American Society of Clinical Oncology/ College of American Pathologists clinical practice guideline update. J Clin Oncol 2013; 31:3997-4013.
15 Cuadros M, Talavera P, López FJ, GarcíaPeréz I, Blanco A, Concha A: Real-time RTPCR analysis for evaluating the Her2/neu status in breast cancer. Pathobiology 2010;77: 38-45.

16 Liu LL, Zhao H, Ma TF, Ge F, Chen CS, Zhang YP: Identification of valid reference genes for the normalization of RT-qPCR expression studies in human breast cancer cell lines treated with and without transient transfection. PLoS One 2015; 10:e117058.

17 Goldhirsch A, Wood WC, Coates AS, Gelber RD, Thürlimann B, Senn HJ; Panel members. Strategies for subtypes - dealing with the diversity of breast cancer: highlights of the St. Gallen International Expert Consensus on the Primary Therapy of Early Breast Cancer 2011. Ann Oncol 2011;22:1736-1747.

18 Skaland I, Øvestad I, Janssen EA, Klos J, Kjellevold KH, Helliesen T, Baak JP: Comparing subjective and digital image analysis HER2/ neu expression scores with conventional and modified FISH scores in breast cancer. J Clin Pathol 2008;61:68-71.

19 Muss HB, Thor AD, Berry DA, Kute T, Liu ET, Koerner F, Cirrincione CT, Budman DR, Wood WC, Barcos M, et al: c-erbB-2 expression and response to adjuvant therapy in women with node-positive early breast cancer. N Engl J Med 1994;330:1260-1266.

20 Criscitiello C, Curigliano G: HER2 signaling pathway and trastuzumab cardiotoxicity. Future Oncol 2013;9:179-181.

21 Khoury T, Sait S, Hwang H, Chandrasekhar $\mathrm{R}$, Wilding G, Tan D, Kulkarni S: Delay to formalin fixation effect on breast biomarkers. Mod Pathol 2009;22:1457-1467.

22 Kontani K, Kuroda N, Hashimoto S, Murazawa $\mathrm{C}$, Norimura S, Tanaka $\mathrm{H}$, Ohtani M, Fujiwara-Honjo N, Kushida Y, Date M, Haba R, Houchi H, Yamauchi A, Yokomise H: Clinical usefulness of human epidermal growth factor receptor-2 extracellular domain as a biomarker for monitoring cancer status and predicting the therapeutic efficacy in breast cancer. Cancer Biol Ther 2013;14:20-28. 
23 Pazhoomand R, Keyhani E, Banan M, Najmabadi $\mathrm{H}$, Khodadadi F, Iraniparast A, Feiz F, Majidzadeh K, Bahman I, Moghadam FA, Sobhani AM, Muhammadnejad A, Abedini SS, Behjati F: Detection of HER2 status in breast cancer: comparison of current methods with MLPA and real-time RT-PCR. Asian Pac J Cancer Prev 2013;14:7621-7628.

24 Takano EA, Mikeska T, Dobrovic A, Byrne DJ, Fox SB: A multiplex endpoint RT-PCR assay for quality assessment of RNA extracted from formalin-fixed paraffin-embedded tissues. BMC Biotechnol 2010;10:89.
25 Kulka J, Tôkés AM, Kaposi-Novák P, Udvarhelyi N, Keller A, Schaff Z: Detection of HER$2 /$ neu gene amplification in breast carcinomas using quantitative real-time PCR - a comparison with immunohistochemical and FISH results. Pathol Oncol Res 2006;12:197204.

26 He J, Wang H, Ma F, Feng F, Lin C, Qian H: Prognosis of lymph node-negative breast cancer: association with clinicopathological factors and tumor associated gene expression. Oncol Lett 2014;8:1717-1724.

27 Fan Y, Guan Y, Zhao WH, Li Q, Xu BH: Clinicopathological characteristics and prognostic factors of breast cancer with estrogen- and progesterone-receptor negative and HER-2 overexpression. Zhonghua Zhong Liu Za Zhi 2008;30:917-920.
28 Fehm T, Müller V, Aktas B, Janni W, Schneeweiss A, Stickeler E, Lattrich C, Löhberg CR, Solomayer E, Rack B, Riethdorf S, Klein C, Schindlbeck C, Brocker K, Kasimir-Bauer S, Wallwiener D, Pantel K: HER2 status of circulating tumor cells in patients with metastatic breast cancer: a prospective, multicenter trial. Breast Cancer Res Treat 2010;124:403412.

29 Reuben JM, Lee BN, Li C, Gao H, Broglio KR, Valero V, Jackson SA, Ueno NT, Krishnamurthy S, Hortobagyi GN, Cristofanilli M: Circulating tumor cells and biomarkers: implications for personalized targeted treatments for metastatic breast cancer. Breast J 2010;16:327-330. 